\title{
GAYA KEPEMIMPINAN DAN PEMBANGUNAN DESA
}

\author{
Oleh:
}

\author{
AMTAI ALASLAN \\ (Dosen STIA Saumlaki)
}

\begin{abstract}
ABSTRAK
Penelitian ini dilakukan untuk mengetahui hubungan antara Gaya Kepemimpinan dengan Pembangunan Desa di Desa Keliobar Kecamatan Tanimbar Utara Kabupaten Kepulauan Tanimbar. Pengumpulan data dilakukan dengan menggunakan kuesioner sebagai instrumen utama penelitan dengan sampel sebanyak 95 responden yang dianalisis dengan menggunakan rumus Korelasi Pearson Produck Moment dan uji signifikasinya dilakukan dengan mengunakan uji t (t-tes)

Hasil penelitian dengan menggunakan rumus Korelasi Pearson Product Momentdiperoleh hasil nilai $r=0,6458$, yangmenunjukan bahwa ada hubungan yang Kuat antara Gaya Kepemimpinan dengan Pembangunan Desa pada interval 0,60 -0,799. Sementara kontribusi Gaya Kepemimpinan) terhadap Pembangunan Desa sebesar 41,70\% sedangkan sisanya 58,30\% ditentukan oleh fakor lain yang tidak sempat diteliti oleh penulis, dan Uji signifikansi dengan mengkonsultasikan nilai t-hitung dengan nilai t-tabel taraf nyata 5\% dengan $\mathrm{N}=95$, diperoleh nilai t-hitung lebih kecil dari nilai t-tabel $(8,15>1,986)$ sehingga dapat dikatakan bahwa hipotesa alternatif (Ha) diterima dan hipotesa nol (H0) ditolak.
\end{abstract}

Kata Kunci : Gaya Kepemimpinan dan Pembangunan Desa

\begin{abstract}
This research was conducted to determine the relationship between leadership style and village development in Keliobar Village, North Tanimbar District, Tanimbar Islands Regency. The data was collected using a questionnaire as the main research instrument with a sample of 95 respondents who were analyzed using the Pearson Produck Moment Correlation formula and the significance test was carried out using the $t$ test ( $t$-test).

The results of the study using the Pearson Product Moment Correlation formula obtained the results of the value of $r=0.6458$, which indicates that there is a strong relationship between Leadership Style and Village Development in the interval $0.60-0.799$. While the contribution of Leadership Style) to Village Development is $41.70 \%$ while the remaining $58.30 \%$ is determined by other factors that have not been examined by the author, and the significance test is by consulting the $t$-count value with the t-table value of $5 \%$ real level with $\mathrm{N}=95$, it is obtained that the $\mathrm{t}$-count value is smaller than the t-table value $(8.15>1.986)$ so that it can be said that the alternative hypothesis $(\mathrm{Ha})$ is accepted and the null hypothesis (H0) is rejected.
\end{abstract}

Keywords: Leadership Style and Village Development 


\section{PENDAHULUAN}

Keberhasilan suatu organisasi baik organisasi swasta maupun organisasi pemerintah baik pada level pusat maupun daerah sangat ditentukan olehkemampuan seorang pemimpin dalam memberikan motivasi kepada bawahan untuk bekerja secara maksimal guna mencapai tujuan dari organisasi. Peran Pimpinan sangat penting dalam suatu organisasi dalam memberikan petunjuk, arahan dan motivasi kepada bawahannya untuk dapat melaksanakan berbagai petunjuk dan arahan dalam bentuk tindakan-tindakan untuk pengembangan organisasi.

\section{Banyak para sarjana yang} memberikan beragam jenis tipe atau gaya kepemimpinan yang telah diterapkan atau akan dapat diterapkan seorang pemimpin dalam suatu organisasi. Masing-masing gaya kepemimpinan tentu memiliki kelemahan dan kelebihannya. Gaya kepemimpinan yang ideal tentunya berdasarkan pada suatu situasi atau kondisi dengan mempertimbangkan berbagai faktor yang ada baik kondisi karyawan maupun lingkungan eksternal organisasi.Hal ini sejalan dengan pendapat Koontz, O'Donnel \& Wehirich (1990:158-259) mengatakan bahwa faktor-faktor situasi yang mempengaruhi seorang pemimpin adalah pekerjaan yang sedang ditangani, lingkungan organisasi, dan karakteristik orang yang mereka hadapi.Masing-masing gaya kepemimpinan memiliki kelebihan dan kelemahan masing-masing. Oleh karena itu, gaya kepemimpinan situasional merupakan gaya kepemimpinan yang perlu diterapkan oleh seorang pemimpin. Hal ini dikarenakan kepemimpinan situasional lebih menitikberatkan pada gaya yang ditampilkan seorang pemimpin sesuai dengan situasi dan kondisi yang dialami. Dengan kata lain, kapan seorang pemimpin bergaya otoriter dan kapan seorang pemimpin bergaya demokrasi tergantung situasi atau masalah yang dihadapi.

Desa sebagai organisasi terkecil dalam Sistem Pemerintahan Negara Kesatuan Republik Indonesia, juga membutuhan sosok seorang pemimpin yang mampu untuk menggerakan anak buahnya sehingga bekerja secara optimal dengan meningkatkan kemampuan dan prestasi kerja. Berdasarkan UndangUndang Nomor 32 tahun 2004 tentang Pemerintahan Daerah pada pasal 127 tentang tugas pokok Kepala Desa untuk melakukan

penyelenggaraan pemerintahan pembangunan dan kemasyarakatan dalam rangka penyelenggaraan urusan pemerintahan umum dan urusan pemerintahan daerah 
dan wilayahnya yang dijabarkan langsung kepada aparatnya.

Keberhasilan penyelenggaraan pemerintahan desa baik pelayanan maupun pembangunan sangat ditentukan oleh kemampuan kepala desa sebagai pucuk pimpinan di desa untuk mampu menggerakan, memberi motivasi, dan mempengaruhi orang-orang (staf desa) agar bersedia melakukan tindakantindakan yang terarah pada pencapaian tujuan melalui keberanian mengambil keputusan tentang kegiatan yang harus dilakukan. Karena pada prinsipnya Kepemimpinan merupakan inti manajemen, karena kepemimpinan merupakan motor atau daya penggerak semua sumber-sumber dan alat-alat (resources) yang tersedia sebagai suatu organisasi.

Agar dapat melaksanakan tugastugas kepemimpinan, seorang kepala desa tentu harus memiliki kemampuan intelektual (Intelegensia Quality), kemampuan emosional (Emotional Quality) dan kemampuan fisik (Physical Quality).Dengan memiliki syarat-syarat seorang pemimpin tersebut, maka seorang kepala desa dapat mengarahkan, mempengaruhi para staf untuk bekerja secara produktif guna mencapai tujuan yang ditetapkan.
Kepala desa sebagai pimpinan tertinggi yang sangat berpengaruh dan menentukan kemajuan desa melalui pembangunan desa dalam upaya peningkatan kualitas hidup dan kehidupan untuk sebesar-besarnya kesejahteraan masyarakat desa. Jadi pada dasarnya, konsep pembangunan desa merupakan aspek yang multi dimensional, seperti yang dijabarkan pada pasal 78 UU No 6 Tahun 2014, bahwa Pembangunan Desa bertujuan meningkatkan kesejahteraan masyarakat Desa dan kualitas hidup manusia serta penanggulangan kemiskinan melalui pemenuhan kebutuhan dasar, pembangunan sarana dan prasarana Desa, pengembangan potensi ekonomi lokal, serta pemanfaatan sumber daya alam dan lingkungan secara berkelanjutan.

Berdasarkan pemikiran tersebut, dikaitkan dengan kondisi riil di Desa Keliobar Kecamatan Tanimbar Utara, Kabupaten Kepulauan Tanimbar memiliki potensi sumberdaya alam yang cukup melimpah, namun masyarakat desa keliobar masih terkategori sebagai desa yang lamban perkembangannya. Hal ini dikarenakan manajemen pemerintahan Desa yang dikelola dengan gaya kepemimpinan kepala desa yang tertutup,tidak transparan dan selalu apatis dalam memberikan pelayanan kepada 
masyarakat serta minimnya partisipasi masyarakat terhadap pembangunan Desa sehingga perlu diketahui bagaimanakah Gaya Kepemimpinan Kepala Desa Dan Hubungannya Dengan Pembangunan Di Desa Keliobar Kecamatan Tanimbar Utara Kabupaten Kepulauan Tanimbar.

\section{LANDASAN TEORI}

\section{Pengertian Pemimpin}

Pemimpin adalah sosok yang paling bertanggung jawab untuk mengantarkan sebuah organisasi mencapai visi dan misi melalui sistem atau cara kerja yang paling efektif.Menurut Kartini Kartono (1994:33), mengatakan bahwa : "Pimpinan dalam pengertian luas ialah seorang yang pimpin, dengan jelas memprakarsai tingkalaku atau mengontrol usaha atau upaya orang lain atau melalui prestasi, kekuasaan atau posisi. Dalam pengertian terbatas, pimpinan adalah seorang yang membimbing dengan bantuan-bantuan kualitas persuasifnya dan akseptensi/penerimaan secara sukarela oleh para pengikutnya".Selanjutnya menurut R. J. Burby mengatakan bahwa yang dimaksud dengan : " pimpinan adalah orang yang oleh kata atau tindakan mendorong orangorang untuk mengikuti dengan sukarela" ( Mannulang, 1996:32).
Dari uraian beberapa pendapat ahli di atas, maka dapat di ketahui bahwa pemimpin adalah orang yang memiliki kemampuan untuk menggerakan dan mempengaruhi orang lain agar mengikutinya dengan sukarela. Sedangkan kepemimpinan merupakan sifat seorang pemimpin untuk menggerakan dan mempengaruhi orang lain. Sementara Kepemimpinan merupakan inti manajemen, karena kepemimpinan merupakan motor atau daya penggerak semua sumber-sumber dan alat-alat (resources) yang tersedia dalam suatu organisasi. Sebagaimana yang dikataka oleh (Miftah Thoha 2004: 264) bahwa Kepemimpinan adalah "kegiatan untuk mempengaruhi perilaku orang lain, atau seni mempengaruhi perilaku orang lain, atau seni mempengaruhi manusia baik perorangan maupun kelompok".

\section{Jenis Dan Macam Gaya Kepemimpinan}

Gaya Kepemimpinan adalah suatau seni kesanggupan atau teknik untuk membuat sekelompok orang - orang mengikuti atau mentaati segala apa yang dikehendakinya dan membuat mereka antusias mengikutinya.Apabila suatu organisasi berjalan dengan lesuh, orang sering mempersoalkan kepemimpinannya seperti pemimpin lemah, tidak pernah masuk kantor dan seterusnya. Memang 
jika kepemimpinan tidak tampak, sering di katakana bahwa organisasi itu tidak mempunyai pemimpin.Tentu bukan ini yang di kehendaki, tetapi kalau organisasi itu berjalan dengan baik dan berkembang dengan pesat orang sering kali lupa membicarakan kepemimpinan. Kehadiran seorang pemimpin dalam suatu organisasi ialah untuk mengerakan orang- orang dalam organisasi dalam mencapai tujuan.

\section{Ada beberapa macam gaya} kepemimpina yang perlu diperhatikan dalam melaksanakan tugas kepemimpina :

a. Gaya kepemimpinan otoriter/authoritarian

Adalah gaya pemimpin yang memusatkan segalah keputusan dan kebijakan yang diambil dari dirinya sendiri secara penuh. Segala pembagian tugas dan tanggung jawab di pegang oleh si pemimpin yang otoriter tersebut, sedangkan para bawahan hanya melaksanakan tugas yang telah diberikan.

b. Gaya kepemimpinan demokratis/democratic

Adalah gaya pemimpin yang memberikan wewenang secara luas kepada para bawahan. Setiap ada permasalahan selalu mengikut sertakan bawahan sebagai suatu tim yang utuh. Dalam gaya kepemimpinan demokratis, pemimpin banyak informasi tentang tugas serta tanggung jawab para bawahannya.

c. Gaya kepemimpina bebas/laissez faire

Pemimpin jenis ini hanya terlibat dalam kuantitas yang kecil di mana para bawahannya yang secara aktif menentukan tujuan dan penyelesaian masalah yang di hadapi.

d. Gaya kepemimpinan Situasional Pendekatan situasional menekankan bahwa gaya yang digunakan adalah bergantung pada faktor-faktor seperti situasi, karyawan, organisasi dan variabelvariabel lingkungan lainnya. Faktor-faktor situasi tersebut yang mempengaruhi seorang pemimpin untuk melaksanakan pekerjaan yang sedang ditangani, lingkungan organisasi, dan karakteristik orang yang mereka hadapi (Koontz, O’Donnel \& Wehirich 1990:158259)
Konsep
Pemerintah
Desa.
Secara umum di Indonesia, desa diatur dalam Undang-Undang Nomor 6 tahun 2014 tentang Desa, menjabarkan 
pengertian desa adalah desa dan desa adat atau yang disebut dengan nama lain, selanjutnya disebut Desa, adalah kesatuan masyarakat hukum yang memiliki batas wilayah yang berwenang untuk mengatur dan mengurus urusan pemerintahan, kepentingan masyarakat setempat berdasarkan prakarsa masyarakat, hak asal usul, dan/atau hak tradisional yang diakui dan dihormati dalam sistem pemerintahan Negara Kesatuan Republik Indonesia.

Pengertian desa dari sudut pandang sosial budaya dapat diartikan sebagai komunitas dalam kesatuan geografis tertentu dan antar mereka saling mengenal dengan baik dengan corak kehidupan yang relatif homogen dan banyak bergantung secara langsung dengan alam. Dalam pasal 1 ayat (3) UU Nomor 6 Tahun 2014 Tentang Desa, dikatakan bahwa pemerintah desa adalah Kepala Desa atau yang disebut dengan nama lain dibantu perangkat Desa sebagai unsur penyelenggara Pemerintahan Desa.Desa dibentuk atas prakarsa masyarakat dengan memperhatikan asalusul desa dan kondisi sosial budaya masyarakat setempat.

\section{Pengertian Pembangunan Desa}

Menurut Ndraha (1990: 16) Pembangunan ialah “ upaya untuk meningkatkan kemampuan manusia untuk mempengaruhi

masa

depannya".Perkataan "desa" menurut Suhardjo Kartohadikusoemo dan Hatta Sastra Mihardja, (1997: Modul 2.2) adalah berasal dari perkataan "Sanskrit" yang artinya tanah air, tanah asal atau tanah kelahiran.

Berkenaan dengan pembangunan desa, Daeng Sudirwo, (1998:63) "Pembangunan desa adalah proses perubahan yang terus menerus dan berkesinambungan yang diselenggarakan oleh masyarakat beserta pemerintah untuk meningkatkan kesejahteraan lahir dan batin, mateeri dan spiritual berdasarkan pancasila yang berlangsung di desa."

Lebih lanjut Ndraha menjabarkan bahwa ada lima implikasi utama defenisi tersebut yaitu:

1. Pembangunan

berarti membangkitkan kemampuan optimal manusia, baik manusia maupun kelompok (capacity).

2. Pembangunan berarti mendorong tumbuhnya kebersamaan dan kemerataan nilai dan kesejahteraan (equity).

3. Pembangunan berarti menaruh kepercayaan kepada masyarakat untuk membangun dirinya sendiri sesuai dengan kemampuan yang ada padanya. Kepercayaan ini dinyatakan dalam bentuk 
kesempatan yang sama, kebebasan memilih, dan kekuasaan untuk memutuskan (empowerment).

4. Pembangunan berarti membangkitkan kemampuan untuk membangun secara mandiri (sustainability).

5. Pembangunan berarti mengurangi ketergantungan negara yang satu dengan negara yang lain dan menciptakan hubungan saling menguntungkan dan saling menghormati (interdependence).

Berdasarkan Undang-Undang Nomor 6 tahun 2014 tentang Desa, pasal 1, Pembangunan Desa adalah adalah upaya peningkatan kualitas hidup dan kehidupan untuk sebesar-besarnya kesejahteraan masyarakat desa. selanjutnya dijabarkan pada pasal $78 \mathrm{UU}$ No 6 Tahun 2014, bahwa Pembangunan Desa bertujuan meningkatkan kesejahteraan masyarakat Desa dan kualitas hidup manusia serta penanggulangan kemiskinan melalui pemenuhan kebutuhan dasar, pembangunan sarana dan prasarana Desa, pengembangan potensi ekonomi lokal, serta pemanfaatan sumber daya alam dan lingkungan secara berkelanjutan.

Agar pembangunan di desa menyentuh seluruh lapisanmasyarakat, maka diterapkan prinsip-prinsip pembangunan, sasaran pembangunan serta pengembangannya. Berikut penjelasan ketiga unsur menurut Rahardjo Adisusmito ( 2006:18-20 ):

a. Prinsip-prinsip pembangunan pedesaan, antara lain :

1. Transparasi.

2. Partisipatif.

3. Dapat dinikmati masyarakat.

4. Dapat dipertanggungjawabkan, dan

5. Berkelanjutan.

b. Sasaran pembangunan pedesaan, adalah untuk terciptanya :

1. Peningkatan produksi dan produktifitas.

2. Percepatan pembangunan desa.

3. Peningkatan ketrampilan dalam berproduksi, pengembangan lapangan kerja dan lapangan usaha produktif.

4. Peningkatan prakarsa, dan

5. Penguatan kelembagaan.

c. Ruang lingkup pengembangan desa, yaitu:

1. Pembangunan sarana dan prasarana.

2. Pemberdayaan masyarakat. 
3. Pengelolaan sumber daya alam dan sumber daya manusia.

4. Penciptaan lapangan kerja, kesempatan berusaha, peningkatan pendapat an, dan

5. Penataan keterkaitan antara kawasan pedesaan dan kawasan perkotaan.

Dengan demikian, maka pembangunan desa perlu terus diupayakan karena secara keseluruhan desa merupakan landasan bagi ketahanan nasional seluruh rakyat Indonesia.Selain itu, untuk mencapai tujuan dari pembangunan desa itu, pelaksanaan pembangunan di berbagai aspek kehidupan baik aspek ideologi, politik, ekonomi, sosial, budaya dan agama maupun dalam aspek pertahanan dan keamanan.Melalui pembangunan desa diupayakan agar masyarakat memiliki keuletan dan ketangguhan yang mengandung kemampuan mengatasi berbagai masalah dalam kehidupan.

\section{Ciri-ciri dan Prinsip Pembangunan} Desa

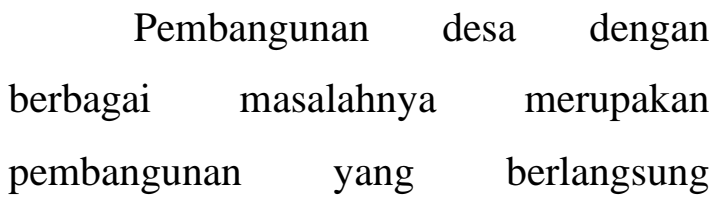

menyentuh kepentingan bersama.Dengan demikian desa merupakan titik sentral dari pembangunan nasional Indonesia. Oleh karena itu, pembangunan desa tidak mungkin bisa dilaksanakan oleh satu pihak saja, tetapi harus melalui koordinasi dengan pihak lain baik dengan pemerintah maupun masyarakat secara keseluruhan. Dalam merealisasikan pembangunan desa agar sesuai dengan apa yang diharapkan perlu memperhatikan beberapa pendekatan dengan ciri-ciri khusus yang sekaligus merupakan identitas pembangunan desa itu sendiri, seperti yang dikemukakan oleh C.S.T Kansil, (2003:251) yaitu:

1. Komprehensif multi sektoral yang meliputi berbagai aspek, baik kesejahteraan maupun aspek keamanan dengan mekanisme dan sistem pelaksanaan yang terpadu antar berbagai kegiatan pemerintaha dan masyarakat.

2. Perpaduan sasaran sektoral dengan regional dengan kebutuhan essensial kegiatan masyarakat.

3. Pemerataan dan penyebarluasan pembangunan keseluruhan pedesaan termasuk desa-desa di wilayah kelurahan. 
4. Satu kesatuan pola dengan pembangunan nasional dan regional dan daerah pedesaan dan daerah perkotaan serta antara daerah pengembangan wilayah sedang dan kecil.

5. Menggerakan partisipasi, prakaras dan swadaya gotong royong masyarakat serta mendinamisir unsur-unsur kepribadian dengan teknologi tepat waktu. Jadi di dalam merealisasikan pembangunan desa itu harus meliputi berbagai aspek, jangan dari satu aspek saja, agar pembangunan desa itu dapat sesuai dengan apa yang diinginkan.

Pembangunan desa itu harus meliputi berbagai aspek kehidupan dan penghidupan artinya harus melibatkan semua komponen yaitu dari pihak masyarakat dan pemerintah, dan harus langsung secara terus menerus demi tercapainya kebutuhan pada masa sekarang dan masa yang akan datang.

\section{METODE PENELITIAN}

Metode yang digunakan dalam penelitian ini adalah metode Kuantitatif asosiatif yakni mencari hubungan antara variabel yang satu dengan variabel yang lain (Sugiono2009:11). Dengan Lokus Penelitian pada Desa Keliobar Kecamatan Tanimbar Utara Kabupaten Kepulauan Tanimbar.

Sampel yang digunakan dalam penelitian ini sebanyak 95 responden yang diukur dengan rumus Slovin pada populasi sebanyak 1.425 orang yang diambil dengan menggunakan teknik purposive sampling dan selanjutnya data dikumpulakan dengan menggunakan kusioner, observasi, wawancara dengan kepustakaan.

Datayang berhasil dikumpulkan dalam penelitian ini akan dianalisa dengan menggunakan alat analaisa statistik Korelasi Pearson Pruduck Moment yaitu :

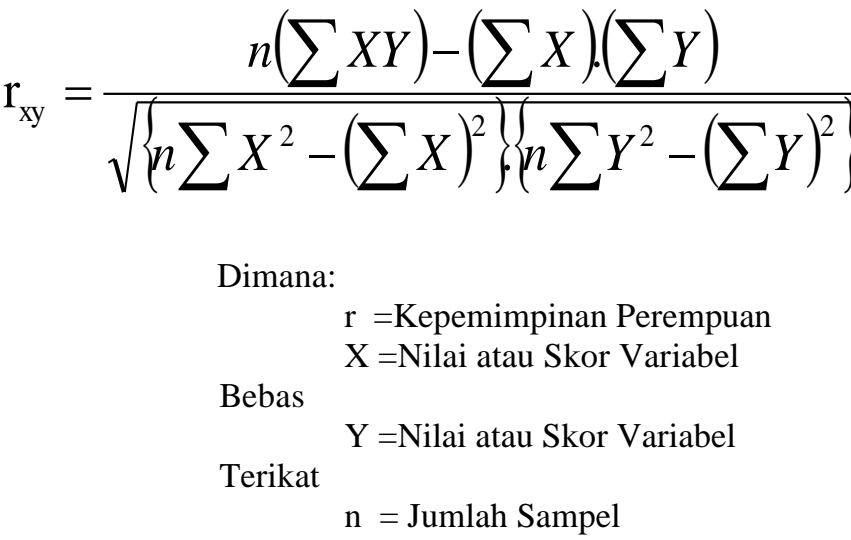

Sedangkan arti harga $\mathrm{r}$ akan dikonsultasikan dengan nilai interpretasi pada tabel Koefisien Korelasi sebagai berikut : 


\begin{tabular}{|c|l|}
\hline Interval Koefisien & $\begin{array}{c}\text { Tingkat } \\
\text { Hubungan }\end{array}$ \\
\hline $0,80-1,000$ & Sangat kuat \\
\hline $0,60-0,799$ & Kuat \\
\hline $0,40-0,599$ & Cukup kuat \\
\hline $0,20-0,399$ & Rendah \\
\hline $0,00-0,199$ & $\begin{array}{l}\text { Sangat } \\
\text { rendah }\end{array}$ \\
\hline
\end{tabular}

Selanjutnya untuk menyatakan

besar kecilnya sumbangan Varibel X terhadap Variabel Y dapat ditentukan dengan rumus Koefisien Determinan sebagai berikut :

$$
K P=r^{2} \times 100 \%
$$

Untuk menguji kebenaran hipotesa penelitian, akan di uji signifikasinya denganrumus uji $\mathrm{t}(t$ test)padatarafnyata5\% $(0,05)$ uji dua arah dengan $\mathrm{dk}=\mathrm{n}-2$ dengan formula sebagai berikut :

$$
t_{\text {hitung }}=\frac{r \sqrt{n-2}}{\sqrt{1-r^{2}}}
$$

Kaidah Pengujian :

Jika $\quad$ Jika $t_{\text {hitung }} \geq t_{\text {tabel}}$, maka signifikan

Jika $t_{\text {hitung }} \leq \mathrm{t}_{\text {tabel}}$, maka tidak signifikan

\section{PEMBAHASAN}

Hasil penelitian menunjukan bahwa variabel Gaya Kepemimpinan berpengaruh/ mempunyai hubungan yang signifikan terhadap Pembangunan di Desa
Keliobar Kecamatan Utara Kabupaten Kepulauan Tanimbar yang akan diuraikan sebagai berikut :

\section{Gaya Kepemimpinan Kepala Desa}

Gaya Kepemimpinan Kepala desa adalah kemampuan seorang kepala desa untuk mempengaruhi dan menggerakkan orang lain (masyarakat desa dan staf pemerintah desa) untuk bekerjasama mencapai suatu tujuan bersama.

Dari hasil penelitan yang dilakukan menunjukan bahwa variabel Gaya Kepemimpinan berpengaruh/ mempunyai hubungan yang signifikan terhadap Pembangunan Desa. Hal ini ditentukan dengan indikator-indikator pembentunya sebagai berikut :
a. Partisipasi masyarakat
b. Menerima
Kritikan masyarakat
c. Kemampuan manajerial
d. Kewibawaan Pimpinan

Keempat indikator ini perlu perlu mendapat perhatian yang maksimal karena mempunyai korelasi terhadap pembangunan di Desa Keliobar. Hal ini dapat dilihat dengan data yang dihasilkan sebagai berikut

1. Untuk pertanyaan pertama mengenai indikator Partisipasi masyarakat ternyata dari 95 
respondent terdapat 26

responden $\quad(27,37 \%)$

menjawab sangat setuju,

kemudian56reponden

$(58,95 \%)$ mejawab setuju, dan yangmenjawab ragu ragu sebanyak 13 responden $(13,68 \%)$.

2. Untuk pertanyaan kedua mengenai indikator menerima kritikan masyarakat ternyata dari 95 responden ternyata 15 responden menjawab sangat setuju, kemudian68responden

$(71,58 \%)$ mejawab setuju, dan yangmenjawab ragu ragu sebanyak 12 responden $(12,63 \%)$.

3. Untuk pertanyaan ketiga mengenai indikator

Kemampuan Manajerial ternyata dari 95 responden terdapat 9 responden $(9,47 \%)$ menjawab sangat setuju, kemudian 55responden $(57,89 \%)$ mejawab setuju, dan yangmenjawab ragu ragu sebanyak 39 responden $(41,05 \%)$ sertayang menjawab tidak setuju 2 responden $(2,10 \%)$
4. Untuk pertanyaan keempat mengenai indikator Kewibawaan pimpinan ternyata dari 95 responden terdapat 9 responden $(9,47 \%)$ menjawab sangat setuju, kemudian41responden $(43,16 \%)$ mejawab setuju, dan yangmenjawab ragu ragu sebanyak 43 responden $(45,27 \%)$, dan 2 responden $(2,10 \%)$ menjawab tidak setuju.

Dari ke empat indikator pada variable bebas diatas yang lebih penting untukdilakukan yaitu indicator Kemampuan Manajerial. Karenatanpa Kemampuan Manajerial yang baik, maka semua program Pembagunan desa yang telah direncanakan tidak dapat berjalan dengan baik.

\section{Pembangunan di Desa Keliobar}

Pembangunan desa adalah seluruh rangkaian usaha yang dilakukan dilingkungan desa yang bertujuan untuk mempertinggi taraf hidup masyarakat desa, serta memperkuat kesejahteraan masyarakat dengan rencana yang dibuat atas dasar musyawarah dikalangan masyarakat desa(Kartasasmita 2001 : 66). 
Hal ini sangat ditentukan oleh indikatorindikator seperti :
a. Tingkat Pendapatan
b. Kualitas hidup
c. Tingkat Pendidikan
d. Sarana dan prasarana

Keempat indikator tersebut gunakan untuk melihat Pembangunan di Desa Lauran yang dapat dijelaskan sebagai berikut :

1. Untuk pertanyaan pertama mengenai indikator Tingkat pendapatan, dari 95 responden didapati bahwa 6 responden $(6,31 \%)$ menjawab sangat setuju dan $55 \quad(57,89 \%)$ menjawab setuju kemudian 32 responden $(33,68 \%)$ menjawab ragu-ragu dan 2 responden $(2,11 \%)$ menjawab tidak setuju.

2. Untuk pertanyaan Kedua mengenai indikator Kualitas hidup ternyata dari 95 responden terdapat 49 responden $(51,58 \%)$ menjawab setuju dan 42 responden $(44,21 \%)$ ragu-ragu menjawab, kemudian 4 (4,21\%) menjawab tidak setuju.

3. Untuk pertanyaan Ketiga mengenai indikator Tingkat Pendidikan ternyata dari 95 responden, terdapat 1 orang
$(1,05 \%)$ menjawab sangat setuju dan 33 responden $(34,74 \%)$ menjawab setuju kemudian 52 responden $(54,73 \%)$ ragu-ragu menjawab dan 9 responden $(9,47 \%)$ menjawab tidak setuju.

4. Untuk pertanyaan Keempat mengenai indikator Sarana Prasarana ternyata dari 95 responden didapati bahwa 1 responden $(1,05 \%)$ menjawab sangat setuju dan 26 responden $(27,37 \%)$ menjawab setuju kemudian 60 responden $(63,16 \%)$ ragu-ragu menjawab dan 8 responden $(8,42 \%)$ menjawab tidak setuju.

Dari ke empat indicator di atas pada variable terikat yaitu Pembangunan Desa, yang perlu untuk perhatikan dan dilakukan yaitu indicator Kualitas Hidup, kerena kulaitas hidup masyarakat yang baik akan sangat berdampak pada kesejahteraan masyarakat dan pembanguan desa setempat.

\section{Gaya Kepemimpinan Terhadap} Pembangunan Desa

Gaya Kepemimpinan Kepala Desa terhadap Pemabangunan Desa merepakan sebuah adalah sebuah 
kepemimpinan yang dilakukan untuk mempengaruhi masyarakat dalam melaksanakan program pembangunan demi terwujudnya kesejahteraan masyarakatdi Desa Keliobar. Untuk mengetahui pengaruh antara Gaya Kepemimpinan dengan Pembangunan Desa akan dianalisis dengan menggunakan rumus Korelasi Pearson Produk, dimana langka pertama yang dilakukan adalan membuat sebuah tabel penolong untuk perhitungan korelasi, dimana yang memuat total keseluruhan jawaban responden atas variabel X (Gaya Kepemimpinan) dan variabel Y (Pembangunan Desa) dimana di peroleh nilai-nilanya sebagai berikut :

$$
\begin{aligned}
& \sum \mathrm{X}=1475, \sum \mathrm{Y}=1296, \sum \mathrm{X}^{2}= \\
& 23169, \sum \mathrm{Y}^{2}=17912, \quad \sum \mathrm{XY}= \\
& 20283, \mathrm{n}=95
\end{aligned}
$$

Dengan data nilai yang telah diperoleh tersebut diatas, kemudian dianalisis dengan menggunakan rumus Korelasi Pearson Produkmaka diperoleh nilai Koefisien Korelasi (r) sebesar 0.645yang jika dikonsultasiskan pada tabel interval koefisien berada pada posisi 0,60 - 0,799 dengan kategori hubungan yang kuat. Dengan demikian antara variabel X (Gaya Kepemimpinan) dan variabel Y (Pembangunan Desa) memiliki hubungan yang kuat.

Untuk mencari besar sumbangan (Kontribusi) variabel gaya kepemimpinan terhadap variabel Pembangunan, maka digunakan rumus koefisien determinasi (Kd) dimana $\mathrm{Kd}=r^{2} \times 100 \%$, maka diperoleh nilai $\mathrm{Kd}$ sebesar 41,70\%. Hal ini menunjukan bahwa variabel Gaya Kepemimpinan memberikan kontribusi sebesar $41,70 \%$ terhadap variabel Pembagunan, sedangkan sisanya 58,30\% ditentukan oleh faktor lain yang tidak sempat diteliti.

Selanjutnya dari nilai korelasi yang telah dieroleh tersebut, maka dilakukan uji signifikansi dengan mengunakan formula uji t (t-test) pada taraf nyata signifikan 5\% $(0,05)$ uji dua arah dengan dk =n-2 (952=93). Diperoleh nilai t-hitung sebesar 8,15 yang jika dikonsultasikan dengan nilai t-tabel pada taraf signifikan 5\% $(0,05) \mathrm{dk}=93(1,986)$ maka diperoleh nilai t-hitung sebesar 8,15 lebih besar dari nilai t-tabel 1,98 $(8,15>1,986)$, sehingga dapat dikatakan bahwa hipotesa $\mathrm{Ha}$ diterima sedangkan hipotesa $\mathrm{H}_{0}$ ditolak. Dengan demikian hipotesa yang diajukan terbukti/teruji kebenarannya yaitu terdapat hubungan yang kuat antara variabel bebas (Gaya kepemimpinan kepala desa) dengan Variabel terikat 
(pembangunan) di Desa Keliobar

Kecamatan Tanimbar Utara Kabupaten

Kepulauan Tanimbar.

\section{KESIMPULAN DAN SARAN}

\section{Kesimpulan}

Berdasarkan hasil analisis yang telah diuraikan untuk mengetahui hubugan antara variabel bebas (Gaya Kepemimpinan) dengan variabel terikat (Pembangunan) maka dapatlah ditarik kesimpulan sebagai berikut :

1. Berdasarkan hasil perhitungan dengan menggunakan rumus Korelasi Pearson Product Momentdiperoleh hasil $\mathrm{r}=0,6458$ hal ini berarti bahwa hubungan antara variabel bebas (Gaya Kepemimpinan) dengan variabel terikat (Pembangunan) Memiliki hubungan yang kuat yang berada pada interval 0,60 - 0,799.

2. Hasil perhitungan koefisien determinasi menunjukan bahwa ada kontribusi variabel bebas (Gaya Kepemimpinan) terhadap variabel terikat (Pembangunan) sebesar $41,70 \%$ sedangkan sisanya $58,30 \%$ ditentukan oleh fakor lain yang tidak sempat diteliti oleh penulis.
3. Untuk Uji signifikan dengan mengkonsultasikan nilai t-hitung dengan nilai t-tabel taraf nyata 5\% dengan $\mathrm{N}=95$, diperoleh nilai $\mathrm{t}-$ hitung lebih kecil dari nilai t-tabel $(8,15>1,986)$ sehingga dapat dikatakan bahwa hipotesa alternatif (Ha) diterima dan hipotesa nol (H0) ditolak. Hal ini menunjukan bahwa terdapat hubungan yang kuat antara variabel bebas (Gaya kepemimpinan kepala desa) dengan Variabel terikat (pembangunan) di Desa Keliobar Kecamatan Tanimbar Utara Kabupaten Kepulauan Tanimbar.

\section{Saran}

Dari hasil analisis dan kesimpulan yang telah dikemukakan diatas, maka berikut ini disampaikan saran yang diharapkan dapat bermanfaat dalam pemecahan permasalahan yang ada, yakni sebagai berikut :

1. Gaya kepemimpinan situasional yang diterapkan oleh Kepala Desa tidak sesuai dengan kondisi Masyarakat sehingga gaya kepemimpinan ini tidak perlu dipertahankan.

2. Kepala desa bersama Staf haruslah mengikuti pelatihan 
kepemimpinan dan studi banding (jika dilakukan oleh pemerintah daerah) sehingga dapat menambah pengetahuan untuk lebih membangun desa kearah yang lebih baik sesuai dengan harapan masyarakat.

3. Keterlibatan masyarakat dan partisipasi masyarakat harus lebih ditingkatkan agar pembangunan dapat tercapai

\section{DAFTAR PUSTAKA}

BintoroTjokroamidjojo.1990. Pengantar Administrasi
Pembangunan. Bandung :
LP3ESHandoko, T. Hani. 1995.
Manajemen. Yogyakarta: BPFE

HuseinUmar,2001, Riset Sumber D aya Manusia dalam Organisasi. Jakarta : Gramedia Pustaka Utama.

Kartasasmita, Ginandjar, 2001. Pembangunan Untuk Rakyat: Memadukan Pertumbuhan Dan Pemerataan, Jakarta : Pustaka CIDESINDO.

Kartono, Kartini. 1992. Pemimpin dan Kepemimpinan. Jakarta: PT. Raja Grafindo Persada

Koontz, Harold. Cyrill O’Donnell, \& Weihrich Heinz, 1990, Management, Eight Edition, New Jersey : McGraw-Hill International Books Company terjemahaan UI Press.
M. Manulang, 1996, Organisasi dan manejemen, Jakarta : Rajawali

Soetopo, Hendiyat dan Wasty Soemanto. 1994. Kepemimpinan dan Supervisi. Jakarta : PT. Bina Aksara

Sugiono. 2009. Metode Penelitian Administrasi Dilengkapi Dengan Metode $R \& D$. CV. Alfabeta : Bandung.

Surjadi, 1997, Pembangunan Masyarakat Desa, Bandung : Penerbit PT. Mandar Maju.

Thoha, Miftah. 2004. Perilaku Organisasi Konsep Dasar dan Aplikasinya. Jakarta: PT. Raja Grafindo Persada

Widodo, Joko. 2006. Good Governance, Telaah dari Dimensi Akuntabilitas dan Kontrol Birokrasi pada era Desentralisasi dan Otonomi Daerah. Surabaya: CV Citra Media.

Undang-undang Nomor 6 Tahun 2014 Tentang Desa

Permendagri No. 66 Tahun 2007 Tentang Perencanaan Pembangunan Desa. 